\title{
SURFACE DISTRIBUTION OF FORAMINIFERA IN A NEW ENGLAND SALT MARSH: PLUM ISLAND, MASSACHUSETTS
}

\author{
J. Richard Jones \\ Department of Geology and Planetary Science \\ University of Pittsburgh, Pittsburgh, Pennsylvania 15260 \\ Barry Cameron \\ Department of Geology, Acadia University \\ Wolfville, Nova Scotia BOP 180 \\ Date Rece1ved October 21, 1987 \\ Date Accepted November 19, 1987
}

\begin{abstract}
Salt marsh agglutinated foraminiferal assemblages, floristic zones and environmental subdivisions along the Plum Island barrier island system in Massachusetts resemble the zonation pattern for coastal marshes in the Maritime Provinces of Canada. Forty-three surface samples from high marsh, low marsh, tidal channel margin and elevated surface environments pielded seven species: Trochammina macrescens, Ir. inflata, Miliammina fusca, Tiphotrocha comprimata. Ammotium salsum. Haplophragmoides bonplandi, and Arenoparella mexicana. Analysis of the dead to living ratios does not show a significant preservational difference among the salt marsh environments. Analysis of the total distributions indicates significant differences among the foraminiferal assemblages as a function of surface environments. The high marsh is characterized by Trochammina macrescens, Tiphotrocha comprimata and two of the less comon species. The low marsh is characterized by Miliammina fusca. Trochammina inflata, and Ammotium salsum. The tidal channel margin assemblage is simflar to that of the low marsh except that Ammotium salsum is no longer significant. Although the elevated marsh surfaces contained no living specimens, a high marsh type assemblage of dead specimens was present. These cosmopolitan foraminiferal assemblages should be valid discriminators for the reconstruction of Holocene salt marsh paleoenvironments in many regions.
\end{abstract}

\begin{abstract}
Dans les marais salants longeant le système de flèches littorales de Plum Island, au Massachusetts, les assemblages de foramintfères agglutinants, les zones floristiques et les subdivisions environnementales observés ressemblent au zonage des marals côtiers des Marltimes. Quarante-trois échantillons de surface des slikkes, schorres, chenaux de marée et bancs de surface élevés ont livré sept espèces: Trochammina macrescens, $T$. inflata, Miliammina fusca, Tiphotrocha comprimata. Ammotium salsum. Haplophragmoides bonplandi et Arenoparrella mexicana. Une analyse des rapports morts/vivants ne montre aucune différence notable entre les environnements de marais salants. Une analyse des distributions totales indique des différences notables entre les assemblages de foraminifères en fonction des environnements de surface. La schorre se caractérise par $T$. macrescens, $T$. comprimata et deux espèces moins communes. La slikke se distingue par $M$. fusca, $T$. inflata et $A$. salsum. Les assemblages de bordure des chenaux de marées ressemblent à la slikke bien qu' $A$. salsum n'y solt plus prépondérant. Bien que les bancs élevés du marais ne contiennent aucun spécimen vivant, on y rencontre un assemblage de spécimens morts typique de la schorre. Ces assemblages cosmopolites de foraminifères devraient pouvoir servir d'indicateurs valides lors de la reconstitution des paléomilieux de marals salants holocenes dans plusieurs régions.
\end{abstract}

[Tradult par le journal]

\section{INTRODUCTION}

Marsh Foraminifera are becoming recognized as valuable paleoenvironmental indicators for Holocene salt marsh environments and sea-level changes (Fig. 1), especially in the Maritime Provinces of Canada (Scott and Mediol1, 1978, 1980a, 1982; Scott et al., 1984; Deonarine, 1979; Smith et al., 1984). However, few studies have compared both living and dead foraminiferal assemblages in the same salt marsh sites for evaluating paleoenvironmental analyses (Murray, 1976; Scott and Medioli, 1980b). The purpose of this paper is to evaluate the distributional relationships of the living salt marsh Foraminifera on the Plum Island barrier island system of northeastern Massachusetts (Fig. 2 ) in order to determine their potential use as indicators of Holocene salt marsh environments.

Marsh Foraminifera are dominated by agglutinated forms which are sensitive to changes in environmental conditions (Phleger and Bradshaw, 1966; Scott and Med1o11, 1978, 1980a; Deonarine, 1979) and are more 1ikely to be preserved in acidic marsh sediments than calcareous species (Poag.
1978). A close correlation exists between salt marsh floral zones and foraminiferal distributions (Phleger, 1965; Scott, 1976; Scott and Mediol1, 1978, 1980a; Deonarine, 1979; Poag, 1981). Marsh organisms must be able to tolerate high1y variable environmental conditions (Murray, 1976). Some foraminiferal species are endemic to restricted coastal environments (Phleger, 1970; Scott and Medioll, 1980a), and some appear to have a somewhat cosmopolitan distribution (Phleger, 1960, 1970; Scott et al., 1983). Restricted coastal waters are dominated by a few foraminiferal taxa (Poag, 1981), with diversity being lowest in the high marsh (Phleger, 1970).

Although Scott and Medioli and their associates have conducted extensive investigations of Nova Scotian, New Brunswick and Prince Edward Island salt marsh surface Foraminifera as well as salt marsh subsurface Foraminifera (Scott and Medioli, 1980a; Scott et al., 1981), there have been few studies of the Foraminifera living within New England salt marshes. Phleger and Walton (1950). Parker and Athearn (1959), and Phleger (1960) described the occurrence of some salt marsh 


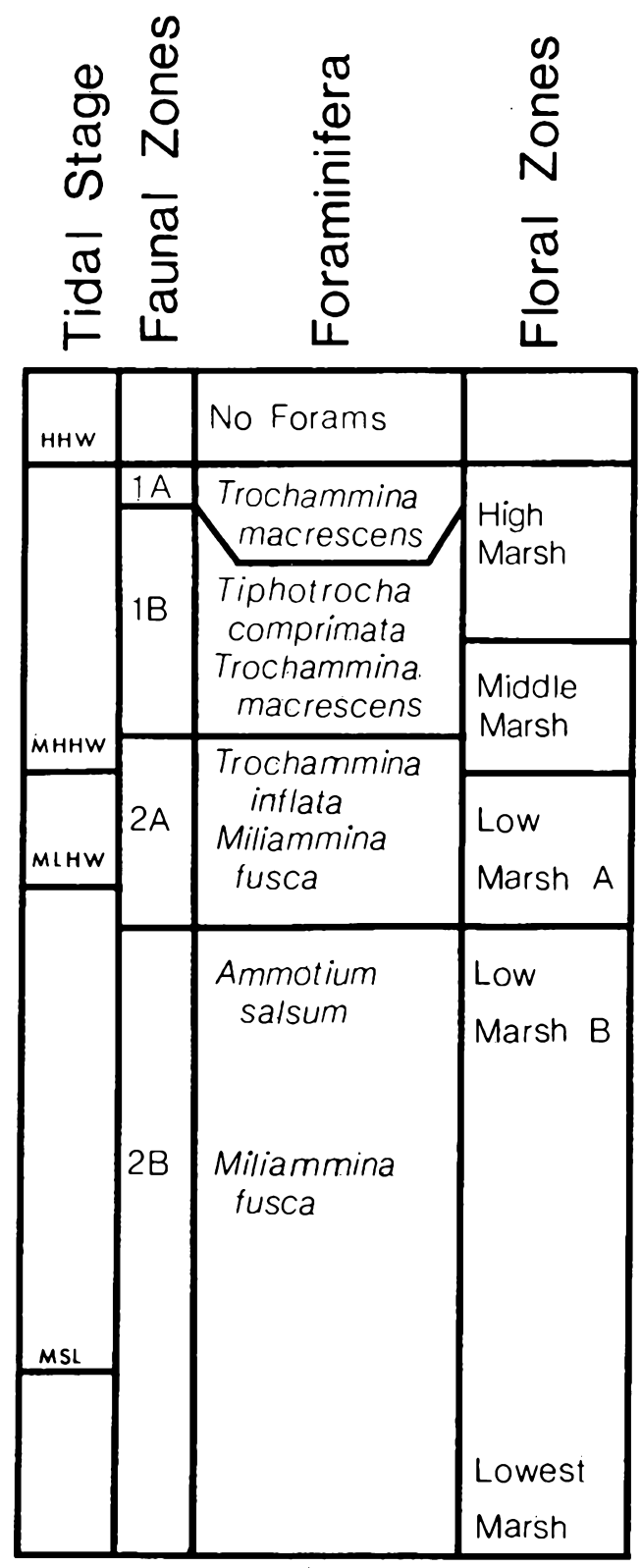

Fig. 1. Zonation of the most diagnostic foraminiferal species with respect to tide level in a Nova Scotian salt marsh (modified from Scott and Mediol1, 1980a). (MSL, mean sea level; MLHW, mean lower high water: MHHW, mean higher high water: HHW, higher high water.)

Foraminifera on Cape Cod, Massachusetts. Jones and Cameron (1983) and Hossley et al. (1985) conducted subsurface reconnaissance studies of the foraminiferal content of the Plum Island salt marsh. Hossley's (1986) more detalled study of Plum Island subsurface marsh Foraminifera included on1y a few surface samples in which the number of live specimens was too low for analysis. These studies suggest, however, that New England marsh species distributions may be similar to those found in other regions such as Texas (Phleger, 1965; Murray, 1976) and California and Nova Scotia (Scott and Mediol1, 1980a).

\section{PLUM ISLAND STUDY AREA}

P1um Island is about $65 \mathrm{kms}$ northeast of Boston. It is $13 \mathrm{kms}$ in length and varles in width from 0.8 to $1.2 \mathrm{kms}$. It is a segment of the barrler islarid system found in the Merrimack River Embayment (Fig. 2). The tidal range for the area is approximately $2.7 \mathrm{~m}$, but major coastal storms frequently increase the average high tide by at least $1 \mathrm{~m}$. The three major geomorphic environments found on mesotidal barrier 1slands are we11-developed. These are: (1) an oceanward sandy beach, (2) a belt of vegetated dunes behind the beach, and (3) a salt marsh developed on the lagoonal side of the 1sland (F1g. 3). The marine fauna and flora of the marsh are included in the Cape Cod to Nova Scotla marine biotic province.

There has been much speculation and controversy over the origin of Holocene barrier islands in general (Fisher, 1968; Hoyt, 1968; Schwartz, 1971, 1973; Leatherman, 1979) and, in particular, over the origin and development of Plum Island. In addition, 1ittle is known about the overall geologic development and blological responses of back-barrier salt marshes (Frey and Basan, 1978). McIntire and Morgan (1963), Rhodes (1973) and Hine (1979) attributed the origin of Plum Island to beach-ridge embayment assoclated with sea-level rise, whereas Jones and Cameron (1977, 1979) and Jones (1984) presented an alternative view that the 1sland formed through a serles of southwardly accreting spits behind which the salt marsh developed.

\section{BACK-BARRIER SALT MARSH}

The Plum Island salt marsh is a new England type salt marsh. New England type salt marshes are mesotidal, divisible into low and high marsh zones on the basis of floral assemblages and extend from the coast of New Jersey to that of Maine (Chapman, 1960). Plum Island is one of the best examples in the northeast coastal region of the United States (U.S. F1sh and W1ldife Serv1ce, 1983). The Marsh represents $42 \%$ of the 14.4 square $\mathrm{km}$ area of Plum Island and is found along almost the entire length of the western margin of the 1sland. Its floral zonation is different enough from other salt marsh areas where recent Foraminifera have been studied, such as Nova Scotla, to warrant a short review.

This back-barrier marsh 1s broadly subdivided Into low marsh and high marsh vegetational zones that are dominated by the salt tolerant grasses Spartina alterntflora and $S$. patens, respectively. The western section of the low marsh proximal to the estuary (F1g. 3) is characterized by the brown alga Fucus vesiculosis and the taller form of Spartina alterniflora. The higher section of the low marsh environment is characterized by the shorter form of S. alterntflara (McDonne11, 1979).

The high marsh environment is a relatively narrow zone (F1g. 3) that occurs above the mean high-water neap tide level and is dominated by Spartina patens. However, S. alterntelora is observed along tidal creeks incised into the high marsh, and it 


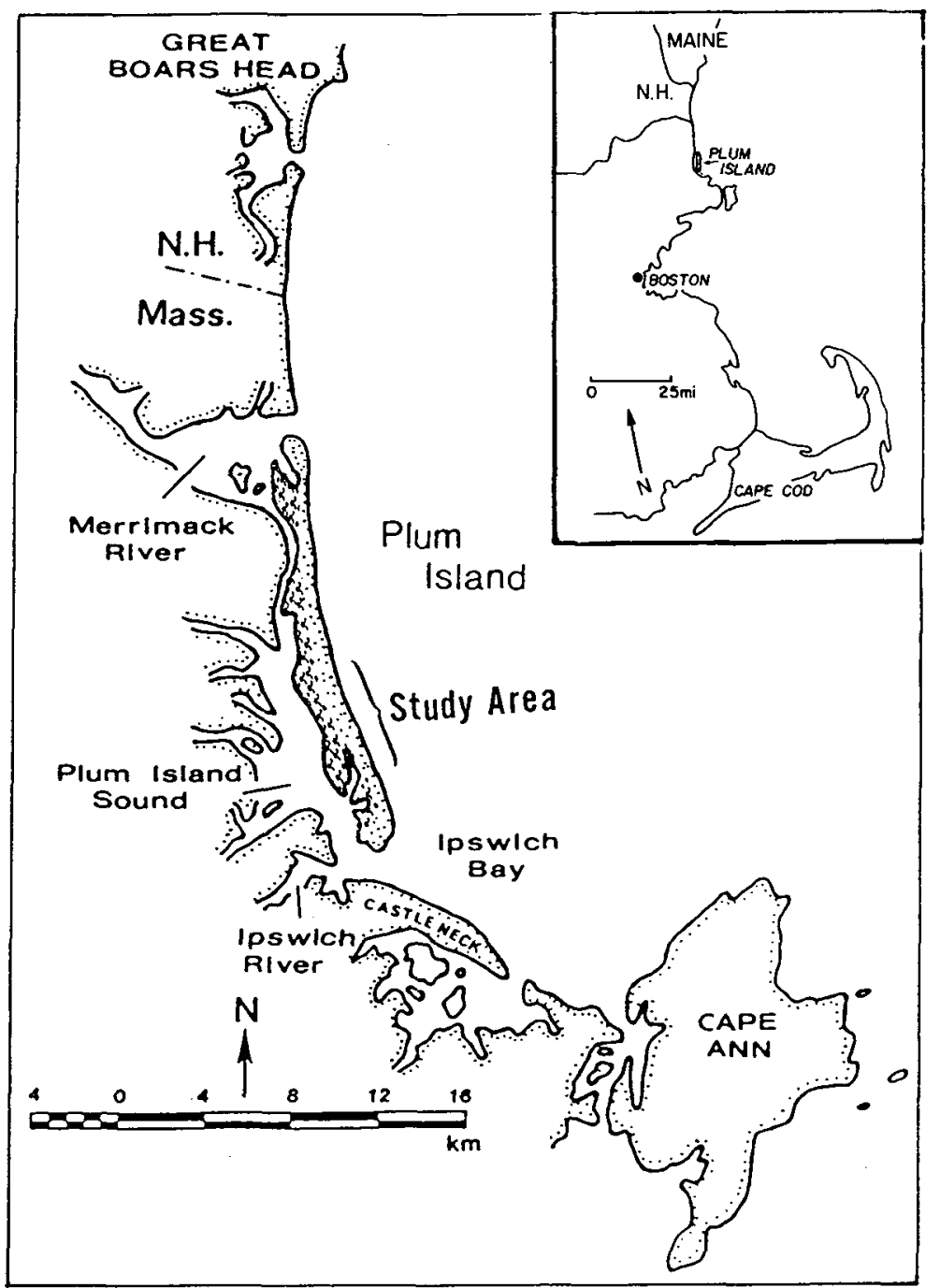

Fig. 2. Location of the Plum Island barrier island system of the Merrimack River Embayment in northeastern Massachusetts. Arrow and bracket denote detailed study area that is illustrated in greater detail in Fig. 3. (Mass., Massachusetts; N.H., New Hampshire.)

also occurs in some depressions. The grass Juncus gerardil is also found along the edges of and on elevated surfaces of the high marsh. Other plant taxa occurring in the high marsh zone include the grass Distichlis and the succulent Salicormia (Redfleld, 1972; McDonne11, 1979). Salt panne depressions in the high marsh are unable to support vascular plants. Quartzose algal mats, produced by photosynthetic sulphur bacteria and cyanobacteria, occur around some of these pannes and along parts of the upper (eastern) fringe of the high marsh (Cameron et al., 1985).

The stratigraphy of the salt marsh consists of low organic content peat horizons (Jones and Cameron, in press), sand lenses and underlying basal sands. The basal sands are found at depths that vary from 0.3 to $5.0 \mathrm{~m}$ (Jones, 1984). The salt marsh sediment is composed of silty-clay units that contain some sand. Salt marsh vegetation comprises from 1 to $60 \%$ of the marsh sediment by volume.

\section{METHODOLOGY}

Forty-three surface samples were collected by standard procedures (Scott and Mediol1, 1980a, p. 7) from high marsh, low marsh, tidal creek banks, and elevated marsh surfaces, such as washover fans (F1g. 3). The delineation of these surface environments was determined in the field on the basis of geomorphology and/or botanical assemblages. A 5\% tincture of rose bengal was added to the sample container in order to differentially stain live specimens. The samples were washed through sieves down to 63 microns, devegetated manua11y and viewed under a $60 \mathrm{X}$ binocular dissecting microscope. When abundances permitted, the first 250 specimens encountered were removed for study. Over 7,200 specimens were counted (Table 1), all identified specimens were attributable to one of the following species: Trochemmina macrescens Brady, Trochamina Inflata (Montagu), Millamina fusca (Brady), Tiphotrocha 


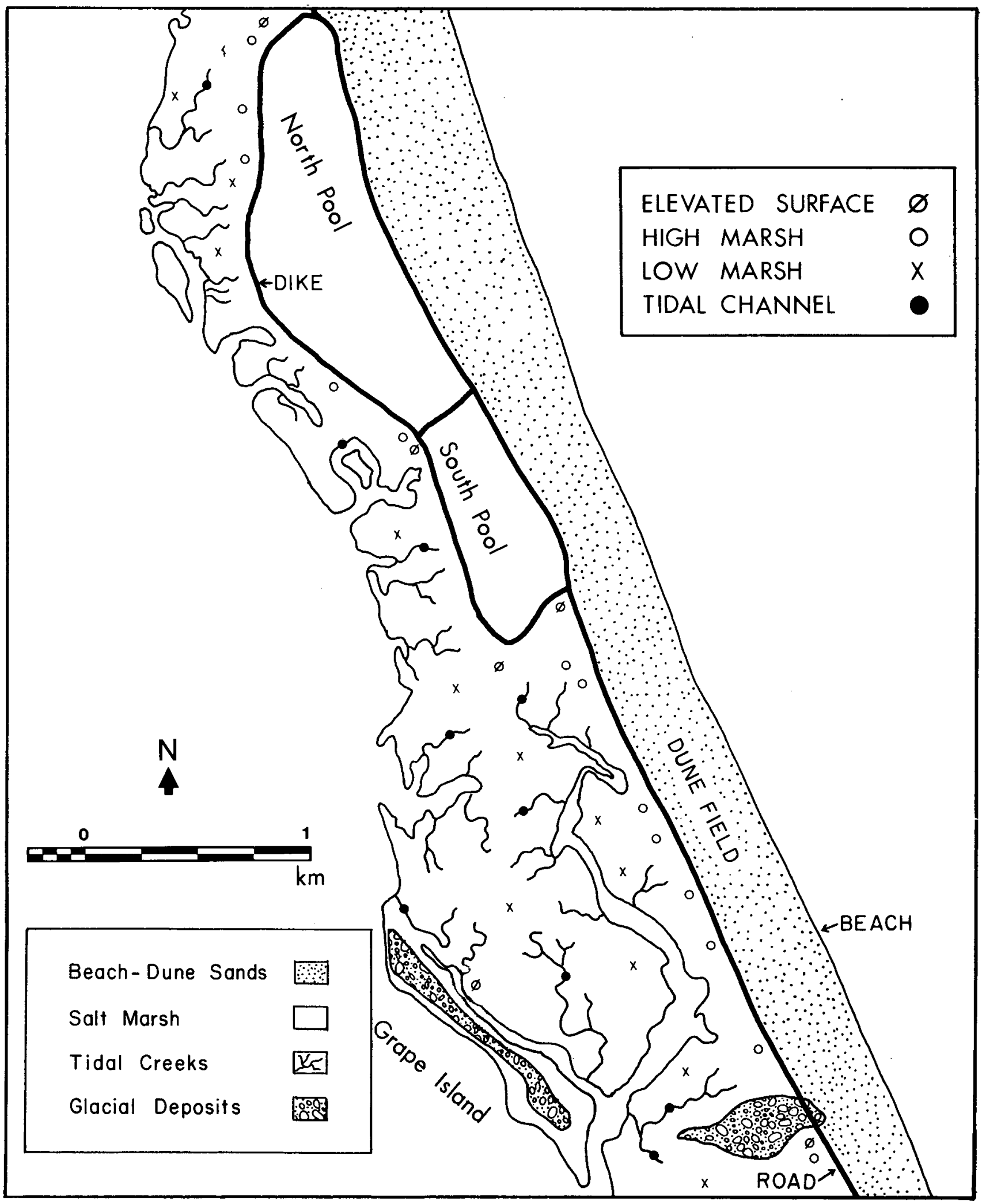

Fig. 3. Sample location map for central Plum Island, Massachusetts (see Fig. 2). Note the narrowness of the high marsh zone and the much broader low marsh zone as indicated by their respect1ve sample symbols. Most of the elevated surface samples occur along the margins of the backdune area, dikes and glaclal deposits. The beach along the oceanward side of the island is too narrow to

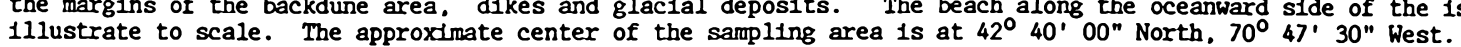


Table 1. Distribution of total foraminiferal specimens in the salt marsh surface environments of Plum Island, Massachusetts*

\begin{tabular}{lcccc}
\hline Species & $\begin{array}{c}\text { High Marsh } \\
\text { (13) }\end{array}$ & $\begin{array}{c}\text { Low Marsh } \\
(14)\end{array}$ & $\begin{array}{c}\text { Tida1 Channe1 } \\
\text { (10) }\end{array}$ & $\begin{array}{c}\text { Elevated } \\
\text { (6)** }\end{array}$ \\
\hline 1. Trochemmina inflata & 226 & 573 & 431 & 147 \\
2. Trochammina macrescens & 771 & 485 & 325 & 216 \\
3. Tiphotrocha comprimata & 576 & 448 & 303 & 113 \\
4. Miliammina fusca & 382 & 736 & 369 & 15 \\
5. Anmotium salsum & 123 & 342 & 97 & 0 \\
6. Haplophragmoides bonplandi & 259 & 92 & 46 & 29 \\
7. Arenoparella mexicana & 57 & 24 & 17 & 0 \\
\hline
\end{tabular}

*Includes 11ve and dead specimens

**Numbers in parentheses refer to the number of samples from each environment.

comprimata (Cushman and Bronnimann), Ammotium salsum (Cushman and Bronnimann), Haplophragmoides bonplandi Todd and Bronnimann, and Arenoparella mextcana (Kornfield). The species nomenclature follows that of Scott and Med1oll (1980a), who reviewed the systematic taxonomy of marsh Foraminifera.

\section{DISTRIBUTION OF LIVE FORAMINIFERA}

A11 seven species of Foraminifera were represented by live specimens as indicated by the stain, but no live specimens occurred in the elevated marsh surface environments. The ratio of dead to living specimens for each species was determined to test if there is a distributional difference among the species in regard to potential preservation within the stratigraphic record (Table 2 ). This analysis has direct applications to the taphonomic implications of benthic Foraminifera as potential indicators of former Holocene salt marsh environments.

The Ch1 square test was used to test for significant differences among the high marsh, low marsh and tidal channel margin environments on the basis of the dead to living ratios (Table 2). The elevated marsh surface samples were eliminated from this analysis because they contained no live specimens. The test results falled to identify a significant difference at the 0.05 level.

These results suggest that there is not a taphonomic overprint, 1.e., an over- or underrepresentation of a particular species within the three environments. These species appear to have

Table 2. Distribution of ratios of dead to living specimens of Foraminifera in the salt marsh surface environments of Plum Island, Massachusetts

\begin{tabular}{lcccc}
\hline Species & $\begin{array}{c}\text { High Marsh } \\
(13) \star\end{array}$ & $\begin{array}{c}\text { Low Marsh } \\
(14)\end{array}$ & $\begin{array}{c}\text { T1dal Channe1 } \\
(10)\end{array}$ & $\begin{array}{c}\text { Elevated } \\
(6)\end{array}$ \\
\hline 1. Trochamina Inflata & 4.0 & 5.2 & 4.9 & 147. \\
2. Trochamina macrescens & 3.7 & 3.2 & 4.6 & 216. \\
3. Tiphotrocha comprimata & 4.6 & 4.1 & 4.3 & 113. \\
4. Milianmina fusca & 6.3 & 5.7 & 6.1 & 15. \\
5. Armotium salsum & 4.3 & 4.0 & 3.9 & 0. \\
6. Baplophragmo1des bompland1 & 3.6 & 4.0 & 4.2 & 29. \\
7. Arenoparella mexicana & 17.3 & 16.7 & 18.4 & 0. \\
\hline
\end{tabular}

*Numbers in parentheses refer to the number of samples from each environment. 
reliable potential for 1dentifying marsh paleoenvironments within the Holocene stratigraphic record.

\section{ANALYSES OF TOTAL SPECIES DISTRIBUTIONS}

The same seven species were identified from dead specimens from the high marsh, low marsh, and tidal channe1 margin environments. Two of the less common species (Anmotium salsum and Arenoparella mexicana), however, were absent from the six elevated surface samples (Table 1). The most abundant species are, in decreasing order, Trochamina macrescens, Millammina fusca, Tiphotrocha comprimata, and Trochamina inflata. The less common species are Anmotium salsum and Haplophragmoldes bonplandi; the least common species is Arenoparella mexicana ( $\mathrm{Fig}, 4$ ). Five of these specles (Trochammina macrescens, Tr. Inflata, Miliamina fusca, Tiphotrocha comprimata, and Anmotium salsum) were considered by Scott and Medioli (1980a) to be diagnostic for salt marsh zonation (Fig. 1). Most have wide geographic distributions. For example, all but $B$. bomplandi

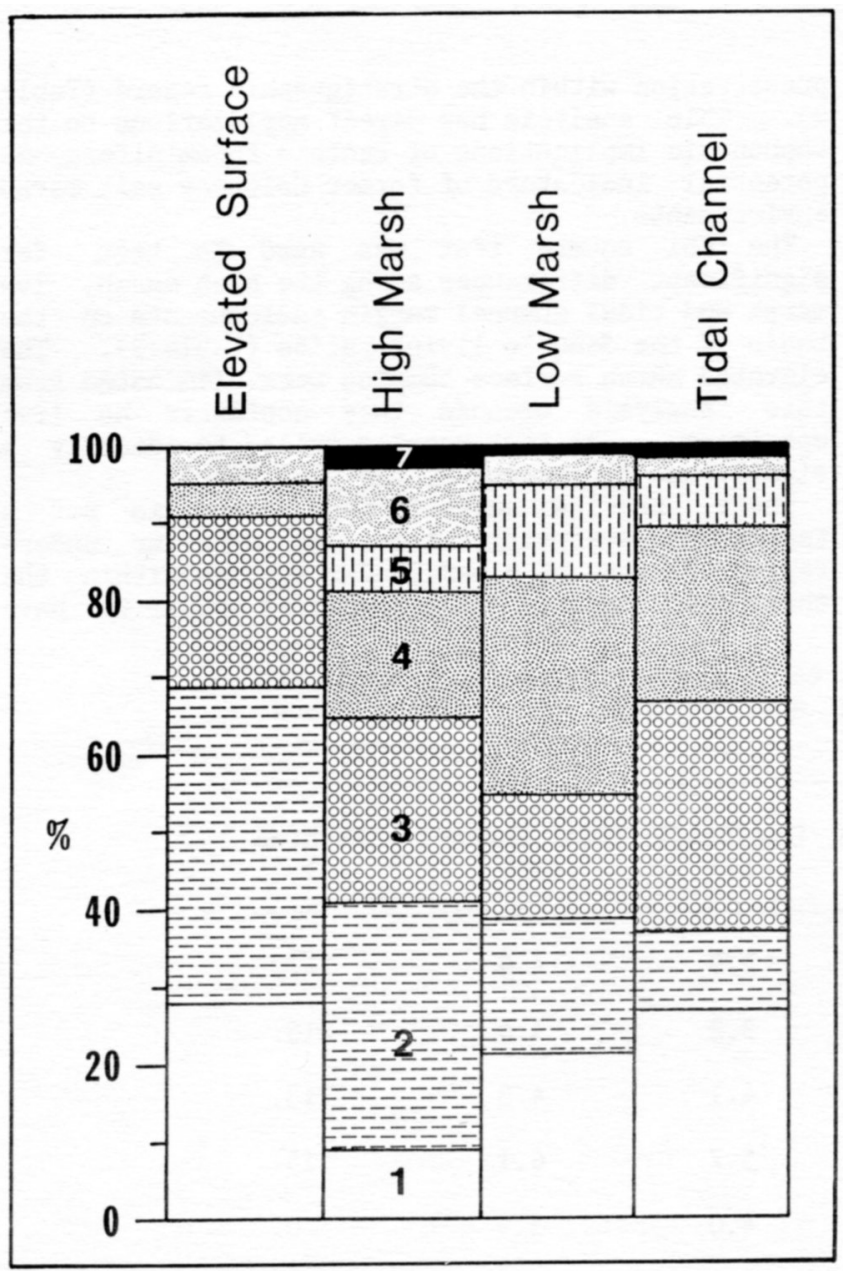

Fig. 4. Percent frequency distribution histograms for surface salt marsh Foraminifera from Plum Island, Massachusetts. 1. Trochammina inflata; 2. Trochamina macrescens; 3 , Tiphotrocha comprimata; 4, Miliammina fusca; 5, Ammotium salsum; 6, Haplophragmoides bonpland1; 7, Arenoparella mexicana. were reported from modern tidal marshes in Galveston Bay, Texas, where there is adequate data on both living and dead foraminiferal assemblages (Murray, 1976).

Scott and Medioli (1980a) presented a generalized zonation model for the distribution of modern foraminiferal species within Nova Scotian salt marshes (Fig. 1), but their distributional pattern has yet to be tested on New England salt marshes. In an attempt to evaluate their model and to determine if a significant difference exists between the respective surface environments and the distribution of foraminiferal species at Plum Island, the ChI square test of significance was computed and a Lorenz curve was constructed from our data. Both the number of living and the number of dead specimens were combined in these analyses, as would eventually be the case with their potential fossil assemblages (Scott and Medioli, 1980b).

The six samples collected from the elevated marsh surfaces were eliminated from the Ch1 square analysis because these data did not meet the assumptions of the test, 1.e., some species were not found in these samples (Table 1). These elevated marsh surface environments probably do not represent a normal in $\nabla$ ivo environment for Foraminifera. The low occurrence of Foraminifera in these areas appears to be the result of transportation by abnormally high tides or storm activity. This interpretation is supported by the dominance of high marsh species and the absence of any living specimens in any of the six samples.

The Chi square test results demonstrate that there is a significant difference at the 0.05 level for the foraminiferal distributions from the three remaining marsh environments. Therefore, certain species prefer specific marsh habitats. The plotted relative frequencies of these seven species by marsh environment are 111ustrated in F1g. 4.

In order to graphically illustrate the abundance and diversity relationships among the seven foraminiferal species in these three marsh environments, a spatial Lorenz curve was constructed (Hammond and McCullagh, 1974). The spatial Lorenz curve method of comparison is frequently used in geographical studies, and it appears to have merit for our distributional study of salt marsh Foraminifera. Other indices of diversity, e.g., Williams' or Simpson's, were not used because they elther depend upon a large number of species or upon the numbers of the more abundant species to produce meaningful results (Reyment, 1971). The spatial Lorenz curve measures concentration by the extent to which a given distribution differs from a hypothetical distribution. The curve is constructed by plotting for each environmental subdivision the frequency of each species as a percentage of the total frequency in the form of a cumulative frequency curve (Table 3. Fig. 5). The total frequencies represent a hypothetical distribution.

The spatial Lorenz curve for our marsh foraminiferal distributions suggests that there are distributional differences among the seven species in the salt marsh environments (Fig. 5). For example, the plotted value for Troahomina inflata is considerably lower for the high marsh environment when compared to the value for this species in the low marsh and tidal creek 
Table 3. Spatial Lorenz cumulative frequency percent distributions of surface salt marsh Foraminifera from Plum Island, Massachusetts

\begin{tabular}{lcccr}
\hline Species & $\begin{array}{c}\text { High Marsh } \\
(13) \star\end{array}$ & $\begin{array}{c}\text { Low Marsh } \\
(14)\end{array}$ & $\begin{array}{c}\text { Tidal Channel } \\
(10)\end{array}$ & Total** \\
\hline 1. Trochemmina inflata & 9.4 & 21.2 & 27.1 & 18.4 \\
2. Trochammina macrescens & 41.6 & 39.1 & 47.6 & 42.1 \\
3. Tiphotrocha comprimata & 65.7 & 55.7 & 66.7 & 62.0 \\
4. Miliamina fusca & 81.5 & 83.0 & 89.9 & 84.3 \\
5. Ammotium salsum & 86.6 & 95.7 & 96.0 & 92.7 \\
6. Haplophragmoides bonplandi & 97.4 & 99.1 & 98.9 & 98.6 \\
7. Arenoparella mexicana & 100.0 & 100.0 & 100.0 & 100.0 \\
\hline
\end{tabular}

* Numbers in parentheses refer to the number of samples from each environment. **Hypothetical distribution

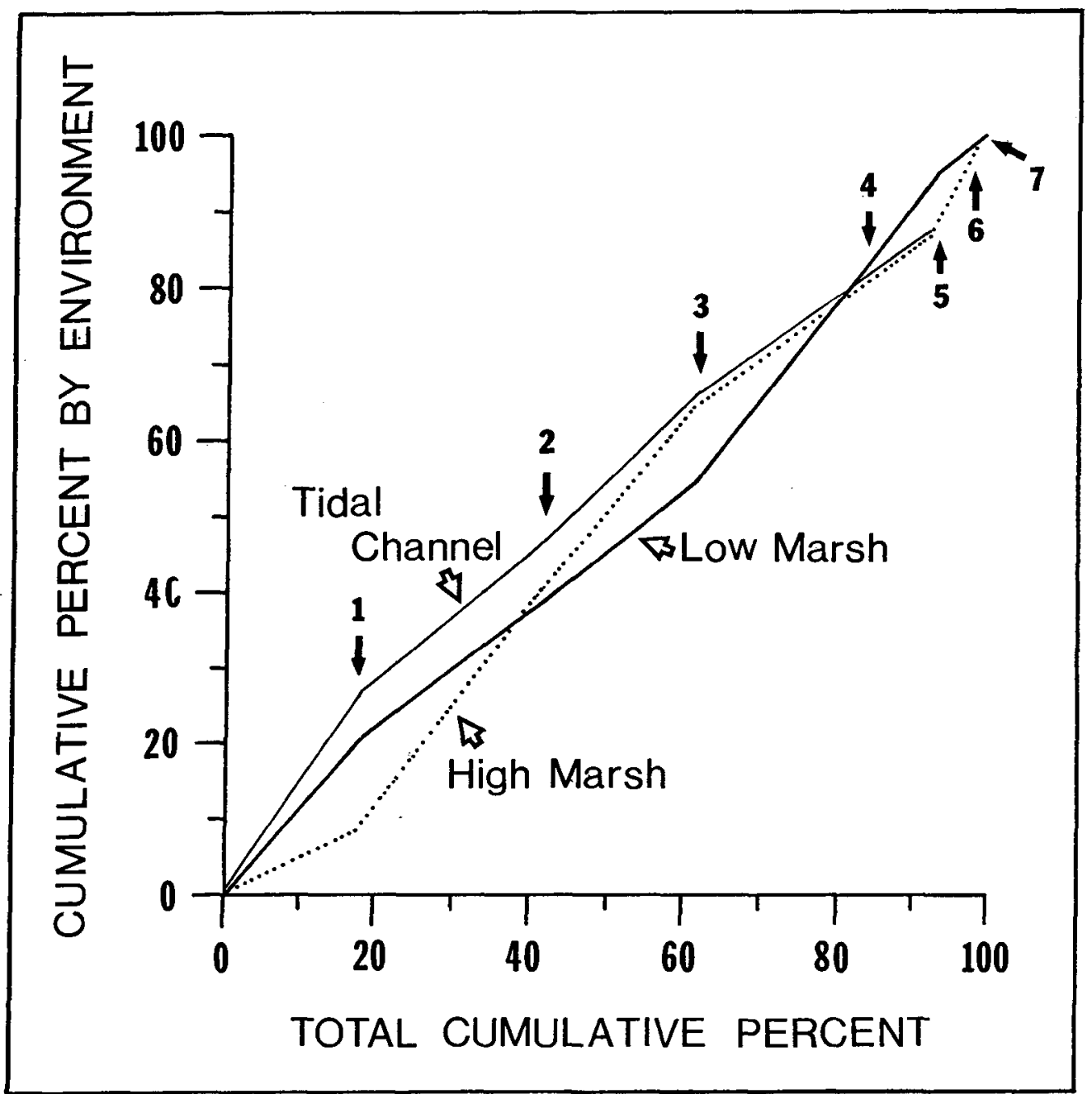

F1g. 5. Spat1al Lorenz curve, based on cumulative frequency percent distributions, for surface salt marsh Foraminifera at Plum Island, Massachusetts. 1. Trochammina inflata; 2. Trochammina macrescens; 3. Tiphotrocha comprimata; 4, Miliammina fusca; 5. Anmotium salsum; 6. Haplophragmoides bonplandi; 7. Arenoparella mexicana. 
environments. The slope of the curve is also greater for Trochamina macrescens in the high marsh environment compared with those for the low marsh and tidal channel environments, suggesting a preferred high marsh habitat for this species. The slopes for Millammina fusca and Anmotium salsum suggest a low marsh habitat for these two species.

In order to more quantitatively determine the most characteristic species associations within these three marsh environments, a similarity index was computed from the data prepared for the Lorenz curve (Table 4). This index is called the "Location Quotient" and is calculated by dividing the respective total frequency value for each species into its frequency value in each environmental subdivision (Hammond and McCullagh, 1974). The larger the value, the more important that particular species is to that environment, regardless of the relative percent contribution. For example, compare the first row values in Tables 3 and 4.

Analysis of the highest values of this index suggests which species are most important to each marsh environment. Examining Table 4, one can see that the high marsh is characterized by the common species Trochammina macrescens and Tiphotrocha comprimata as well as the less common species Haplophragmoldes bonpland1 and Arenoparella mexicana. The low marsh environment is characterized by the common species Miliamina fusca and Trochammina inflata and the less common species Ammotium salsum. The tidal channel margins are characterized by Trochamina inflata and Miliammina fusca.

\section{DISCUSSION}

These species assemblages correspond reasonably well with those of Scott and Medioll (1980a), even though their marsh subdivisions were somewhat different from ours (Figs. 1 and 6), 1.e., we recognize two instead of three major floral subdivisions.

The more common species that characterize our high marsh environment (Trochammina macrescens and
Tiphotrocha comprimata) also characterize most of their high marsh and the upper part of their middle marsh subdivisions. However, we find a significant association of the less common species Haplophragmoldes bonplands and Arenoparella mexicana with our high marsh environment which they did not note for their high or middle marsh environments (Table 4; Figs. 1 and 6 ).

The three species characterizing our low marsh environment are also included in Scott and Medioli's 11st of important species in their lower middle and lower marsh zones (Figs. 1 and 6).

Our tidal channel margin subdivision may be distinct from their "2 B Low Marsh" faunal zone which is characterized by Miliemina fusca, Ammotium salsum and Cribrononion umbilicatulum. Our channel margin environment is dominated by Trochammina inflata, which increases in importance from the low marsh, and villammina fusca, which becomes a less significant major contributor. Ammotium salsum, on the other hand, is no longer a characteristic species (Table 4; Fig. 6).

Our elevated high marsh surface may or may not be analogous to Scott and Medioli's "1 A High Marsh" faunal zone in which they found Trochammina macrescens dominant. Our highest marsh environment contained no live specimens and the dead specimen assemblage was dominated by $\mathrm{Tr}$. macrescens as well as $\mathrm{Tr}$. Inflata and contained average relative contributions from Tiphotrocha comprimata and Haplophragmoides bonplandt.

\section{CONCLUSIONS}

Live Foraminifera on the surface of the modern salt marsh at Plum Island, Massachusetts, were found in only high marsh, low marsh and tidal channel margin environments. Elevated surfaces, such as former washover fans, contained only dead specimens transported primarily from the surrounding high marsh. The ChI square test indicates that there is no significant difference in the dead to live ratios among the three remaining environments. Therefore, agglutinated marsh Foraminifera appear to be potentially good

Table 4. Location Quotient index of similarity for Foraminifera from salt marsh surface environments at Plum Island, Massachusetts

$\begin{array}{llll}\text { 1. Trochamina inflata } & 0.51 & 1.15 * & 1.47 \star \\ \text { 2. Trochamina macrescens } & 1.36 * & 0.76 & 0.87 \\ \text { 3. Tiphotrocha comprimata } & 1.21 * & 0.83 & 0.96 \\ \text { 4. Millammina fusca } & 0.72 & 1.22 \star & 1.04 \star \\ \text { 5. Ammotium salsum } & 0.61 & 1.51 * & 0.73 \\ \text { 6. Haplophragmoldes bonplandi } & 1.82 \star & 0.57 & 0.49 \\ \text { 7. Arenoparella mexicana } & 1.62 \star & 0.61 & 0.73\end{array}$




\begin{tabular}{|l|l|l|}
\hline \multicolumn{1}{|c|}{$\begin{array}{c}\text { Dominant } \\
\text { Foraminifera }\end{array}$} & \multicolumn{1}{c|}{$\begin{array}{c}\text { Dominant } \\
\text { Flora }\end{array}$} & $\begin{array}{c}\text { Marsh } \\
\text { Environment }\end{array}$ \\
\hline \multirow{2}{*}{$\begin{array}{l}\text { Trochammina macrescens } \\
\text { Tiphotrocha comprimata } \\
\text { Arenoparella mexicana } \\
\text { Haplophragmoides bonplandi }\end{array}$} & $\begin{array}{l}\text { Juncus gerardii. } \\
\text { Sistichlis sp. } \\
\text { Salicornia sp. } \\
\text { Cyanophyte mats }\end{array}$ & High Marsh \\
\hline $\begin{array}{l}\text { Ammotium salsum } \\
\text { Miliammina fusca } \\
\text { Trochammina inflata }\end{array}$ & $\begin{array}{c}\text { Spartina alterniflora } \\
\text { (short form) }\end{array}$ & Low Marsh \\
\hline $\begin{array}{l}\text { Miliammina fusca } \\
\text { Trochammina inflata }\end{array}$ & $\begin{array}{c}\text { Spartina alterniflora } \\
\text { (tall form) }\end{array}$ & $\begin{array}{l}\text { Tidal Channel } \\
\text { Upper Margin }\end{array}$ \\
\hline
\end{tabular}

F1g. 6. Zonation of the most diagnostic salt marsh Foraminifera with respect to salt marsh flora and environmental subdivisions at Plum Island, Massachusetts.

indicators for identifying marsh paleoenvironments within the Holocene stratigraphic record.

The overall distribution of total (1ive plus dead) marsh Foraminifera at Plum Island is similar to that presented by Scott and Med1oll (1980a) for Nova Scotian salt marshes but differs in several important ways. Although both areas contain a high marsh Trochamina macrescens-Tiphotrocha comprimata assemblage, our findings also indicate that the less abundant Baplophragmoides bomplands and Arenoparella mexicana are also characteristic of the high marsh on Plum Island. The low marsh in both areas is associated with a Miliamina fusca Trochamina inflata - Ammotium salsum assemblage. The lowest marsh elevation along tidal channel margins at Plum Island is associated primarily with Trochemuntna Inflata and to a lesser degree with Millamina fusca. This may differ from Nova Scotian lowest marsh areas which are characterized by an Anmotium salsum-Miliamnina fusca assemblage.

Assuming that the environmental factors that control the widespread distribution of marsh Foraminifera today also affected these assemblages In a similar manner during the Holocene, a study of their distribution in marsh stratigraphic sequences in many coastal regions could provide a means of identifying former salt marsh subenvironments and assoclated changes resulting from sea-level fluctuations.

\section{ACKNOWLEDGEMENTS}

The officials of the Parker River National Wildilfe Refuge are thanked for permitting research on Plum Island. The Natural Sclences and Engineering Research Council of Canada (Operating Grant No. A8426 to Cameron and General Grant to Acadia University) and the Appalachian Basin Industrlal Assoclates (ABIA research grant to Jones) each provided partial funding for this profect. Lt. James Hossley assisted with preliminary field work.
CAMERON B. CAMERON, D. and JONES, J.R. 1985. Modern algal mats in intertidal and supratidal quartz sands, northeastern Massachusetts, U.S.A. In Biogenic structures: their use in interpreting depositional environments. Edited by H.A. Curran Society of Economic Paleontologists and Mineralogists. Spec1al Publication Number 35. pp. 211-223.

Mineralogists, Special Publication Number 35 , pp. $211-223$.
CHAPMAN, V.J. 1960. Salt Marshes and Salt Deserts of the World. Interscience Publishers, New York, $382 \mathrm{p}$.

DEONARINE, B. 1979. Foraminiferal distribution in two Nova Scot1a marshes. Maritime Sediments, 15, pp. 35-46.

FISHER. J.J. 1968. Barrier 1sland formation: discussion. Geological Soclety of American Bulletin, 79, pp. 1421-1425.

FREY, R.W. and BASAN, F.B. 1978. Coastai sait marshes. In Coastal sedimentary envifonments. Edited by R.A. Davis. Springer-Verlag, New York pp. 101-169.

HAMMOND, R., and MCCULLAGH, P.S. 1974. Quantitative techniques in geography. Clarendon Press, Oxford, $318 \mathrm{p}$.

HINE, J. 1979. Landward migration of barrier 1sland sands under stable sea level conditions: Plum Island, Massachusetts (discussion). Journal of Sedimentary Petrology, 49, pp. 323325.

HOSSLEY. J.G. 1986. Use of salt marsh Foraminifera in developing a model for the evolution of a barrier 1sland: Plum Island, Massachusetts, U.S.A. M.Sc. thesis, Acadia University, Wolfville, Nova Scotia, 182 p.

HOSSLEY, J. CAMERON, B., and JONES, J.R. 1985. Blostrat1graph1c approach to Holocene marsh development. Plum Island, Massachusetts, U.S.A. Maritime Sediments and Atlantic Geology, 21, p. 37

HOYT, J.H. 1968. Barrier 1sland formation: reply. Geological Society of America Bulletin, 79, pp. 1427-1432.

JONES, J.R. 1984. Depositional environments assoclated with paleospit development: P1um Island. Massachusetts. Physical Geography, 5. pp. 206-220.

JONES, J.R. and CAMERON, B. 1977. Landward migration of barrier 1sland sands under stable sea leve1 conditions: Plum Island. Massachusetts. Journal of Sedimentary Petrology, 47. pp. 1475-1483.

JONES, J.R., and CAMERON, B. 1979. Rep1y: Landward migration of barrier 1sland sands under stable sea level conditions: Plum Island, Massachusetts. Journal of Sedimentary Petrology. 49. Pp. $325-330$

JONES, J.R., and CAMERON, B. 1983. The evolution of Barrier 1slands: a biostratigraphic approach. Abstracts with Programs, Geological Society of America, 15, p. 13.

JONES, J.R. and CAMERON, B. In press. Modern coastal backbarrier environment: analog for coal basin or carbonaceous black shale. Geology.

LEATHERMAN, S.P. 1979. Barrler 1slands. Academic Press, New York, $x 1 v$ and $325 \mathrm{p}$.

MCDONNELL. M.J. 1979. The flora of Plum Island, Essex County. Massachusetts. University of New Hampshire Agricultural 
Experiment Station Bulletin, 513, 48 p.

MCINTIRE, W.G., and MORGAN, J.P. 1963. Recent geomorphic history of Plum Island, Massachusetts, and adjacent coasts. Louisiana State University Coastal Studies Serles, Number 8. $44 \mathrm{p}$.

MURRAY, J.W. 1976. Comparative studies of living and dead benthic foraminiferal distributions. In Foraminifera Volume 2. Edited by R.H. Hedly and C.G. Adams. Academic Press. New York, pp. 45-109.

PARKER F.L. and ATHEARN, W.D. 1959. Ecology of marsh foraminifera in Poponessett Bay, Massachusetts. Journal of Paleontology. 33, pp. 333-343.

PHLEGER, F.B. 1960. Ecology and Distribution of Recent

Foraminifera. The Johns Hopkins Press, Baltimore, 297 p.

PHLEGER, F.B. 1965. Pattern of marsh foraminifera, Galveston Bay, Texas. LImnology and Oceanography. 10. supplement. pp. R169-R184

PHLEGER, F.B. 1970. Foraminiferal populations and marine marsh processes. Limnology and Oceanography, 15, pp. 522-534.

PHLEGER, F.B. and BRADSHAW, J.S. 1966. Sedimentary environments in a marine marsh. Science, 154. pp. 1551-1553.

PHLEGER, F.B. . and WALTON, W.R. 1950. Ecology of marsh and bay foraminifera, Barnstable, Massachusetts. American Journal of Sclence, 248, pp. 274-294.

POAG, C.W. 1978. Paired foraminiferal ecophenotypes in Gulf coast estuarles: ecological and paleontological implications. Gulf Coast Association of Geological Societies Transactions Number 28. Part 2. pp. 395-421.

REDFIELD, A.C. 1972. Development of a New England salt marsh. Ecological Monographs, 42, pp. 201-237.

REYMENT, F.A. 1971. Introduction to Quant1tat1ve Paleoecology. Elsevier Publishing Company. New York. 226 p.

RHODES, E.G. 1973. Pleistocene-Holocene sediments interpreted by seismic refraction and washbore sampling, Plum IslandCastle Neck, Massachusetts. United States Army Corps of Engineers Coastal Research Center Technical Memorandum, Number 40. $75 \mathrm{p}$.

SCHWARTZ, M.L. 1971. The multiple causality of barrier 1slands. Journal of Geology, 79, pp. 91-94.

SCHWARTZ. M.L. 1973. Introduction. In Barrier Islands. Edited by M.L. Schwartz. Dowden, Hutchinson and Ross, Inc. pp. 1-2.
SCOTT, D.B. 1976. Quantitative studies of marsh foraminiferal patterns in southern California and their application to Holocene stratigraphic problems. In First International Symposium on Benthonic Foraminifera of Continental Margins, Part A, Ecology and Blology. Edited by C.T. Schafer and B.R. Pelletier. Maritime Sediments, Special Publication 1. pp. 153-170.

SCOTT, D.. GRADSTEIN, F., SCHAFFER, C., MILLER, A. , and WILLIAMSON, M. 1983. The recent as a key to the past: does it apply to agglutinated foraminiferal assemblages? In Proceedings of the First Workshop on Arenaceous Foraminifera. 7-9 September 1981. Edited by J.G. Verdenius, J.E. van Hinte, and A.R. Fortuin. Continental Shelf Institute, Trondhein. Norway, pp. 147-157.

SCOTT, D.B. and MEDIOLI, F.S. 1978. Vertical zonations of marsh foraminifera as accurate indicators of former sealevels. Nature, 272, pp. 528-531.

SCOTT, D.B., and MEDIOLI. F.S. 1980a. Quantitative studies of marsh foraminiferal distributions in Nova Scotia: Implications for sea level studies. Cushman Foundation for Foraminiferal Research Special Publication 17, $37 \mathrm{p}$.

SCOTT, D.B., and MEDIOLI, F.S. 1980b. Living vs. total foraminiferal populations: their relative usefulness in paleoecology. Journal of Paleontology, 54, pp. 814-831.

SCOTT, D.B. and MEDIOLI, F.S. 1982. Micropaleontological documentation of early Holocene fall of relative sea leve1 on the Atlant1c coast of Nova Scot1a. Geology, 10, pp. 278-281.

SCOTT, D.B., MEDIOLI, F.S. and DUFFETT, T.E. 1984. Holocene rise of sea level at Sable Island, Nova Scotia, Canada. Geology, 12, pp. 173-176.

SCOTT, D.B., WILLIAMSON, M.M. and DUFFETT, T.E. 1981. Marsh Foraminifera of Prince Edward Island: their recent distribution and application for former sea level studies. Maritime Sediments and Atlantic Geology, 17, pp. 98-129.

SMITH, D.A. SCOTT D.B. and MEDIOLI, F.S. 1984. Marsh Foraminifera in the Bay of Fundy: modern distribution and application to sea-level determination. Maritime Sediments and Atlantic Geology, 20. pp. 127-142.

UNITED STATES FISH AND WILDLIFE SERVICB. 1983. Final Environmental Impact Statement, Parker River Nat1onal Wildilfe Refuge Master Plan. Department of the Interfor, $183 \mathrm{p}$. 